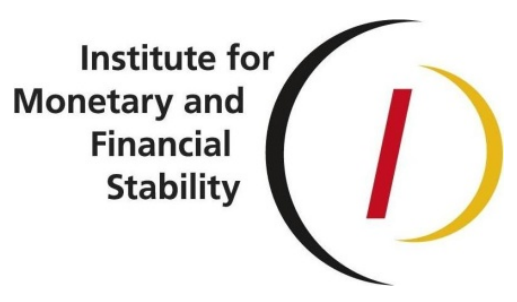

ROMAN INDERST

HOLGER MÜLLER

Bank capital structure and credit decisions

Institute for Monetary and Financial Stability

JOHANN WOLFGANG GOETHE-UNIVERSITÄT FRANKFURT AM MAIN

WorkING PAPER SERIES No. 31 (2009) 
Prof. Dr. Helmut Siekmann (HRSg.)

INSTITUTE FOR MONETARY AND FINANCIAL STABILITY

PROFESSUR FÜR GELD-, WÄHRUNGS- UND NOTENBANKRECHT JOHANN WOLFGANG GOETHE-UNIVERSITÄT

GRÜNEBURGPLATZ 1

60629 FRANKFURT AM MAIN

TELEFON: (069) $798-34014$

TELEFAX: (069) $798-33913$

E-MAIL: GELD-UND-WAEHRUNG@IMFS-FRANKFURT.DE 
ROMAN INDERST

HOLGER MÜLLER

Bank capital structure and credit decisions

Institute for Monetary and Financial Stability

JOHANN WOLFGANG GOETHE-UNIVERSITÄT FRANKFURT AM MAIN

Working PAPER SERIES No. 31 (2009) 


\title{
Bank capital structure and credit decisions
}

\author{
Roman Inderst ${ }^{\mathrm{a}, \mathrm{b}, \mathrm{c}, \mathrm{d}}$, Holger M. Mueller ${ }^{\mathrm{c}, \mathrm{d}, \mathrm{e}, *}$ \\ a University of Frankfurt (IMFS), Germany \\ ${ }^{\mathrm{b}}$ London School of Economics, UK \\ c CEPR, UK \\ d ECGI, Belgium \\ e New York University, USA \\ Received 28 December 2005
}

Available online 21 March 2008

\begin{abstract}
This paper argues that banks must be sufficiently levered to have first-best incentives to make new risky loans. This result, which is at odds with the notion that leverage invariably leads to excessive risk taking, derives from two key premises that focus squarely on the role of banks as informed lenders. First, banks finance projects that they do not own, which implies that they cannot extract all the profits. Second, banks conduct a credit risk analysis before making new loans. Our model may help understand why banks take on additional unsecured debt, such as unsecured deposits and subordinated loans, over and above their existing deposit base. It may also help understand why banks and finance companies have similar leverage ratios, even though the latter are not deposit takers and hence not subject to the same regulatory capital requirements as banks.

(c) 2008 Elsevier Inc. All rights reserved.
\end{abstract}

JEL classification: G21; G32

\section{Introduction}

This paper calls into question a common benchmark in the literature, namely, that all equityfinanced banks have first-best incentives to take on risks. We argue instead that all-equity financed banks are inefficiently conservative in their credit decisions. Leverage is therefore beneficial, at

\footnotetext{
* Corresponding author at: Department of Finance, Stern School of Business, 44 West Fourth Street, New York, NY 10012, USA. Fax: +1 2129954233 .

E-mail addresses: r.inderst@1se.ac.uk (R. Inderst), hmueller@stern.nyu.edu (H.M. Mueller).
} 
least up to a certain point, as it induces banks to take on more risks, thereby mitigating their excessive conservatism.

Our theory of optimal bank leverage may help understand why financial institutions, in contrast to non-financial firms, are so highly levered. The argument we present is based on the role of financial institutions as providers of loans and is not mechanically linked to their role as deposit takers. This is important, for deposit-taking financial institutions have substantial liabilities over and above their deposit base, e.g., in the form of subordinated debt. For example, in 2000 commercial banks' nondeposit liabilities (e.g., notes and bonds) accounted for 26.8 percent of their total liabilities (Saunders and Cornett, 2003).

Our model builds on the model of informed lending by Inderst and Mueller (2006, 2007). Two assumptions are key in that model. First, as banks do not own the projects in which they invest, competition ensures that they cannot extract all of the proceeds from the project. Second, banks are sophisticated lenders who conduct a credit risk analysis before originating new loans. Similar to Stein's (2002) notion of "soft information," the loan officer receives an informative but non-contractible signal about the project to be financed. Loan officers, whose primary task is to make informed credit decisions using their own judgment, can draw on personal experience from making loans to similar firms in the past. ${ }^{1}$

Unlike this paper, the focus in Inderst and Mueller $(2006,2007)$ is on the contract design with the borrower. Inderst and Mueller (2006) focus on the optimal security design in a setting with a continuum of cash flows, while Inderst and Mueller (2007) focus on the optimal use of collateral in contracts with the borrower. In both papers, lenders are assumed to be all-equity financed. Hence, the issue of the lender's own capital structure is ignored.

Since all-equity financed banks are too conservative in their credit decisions, banks must lever up sufficiently to have first-best incentives to take on new risks. However, banks may take on too much leverage and, consequently, engage in excessive risk-taking if they have access to insured deposits without paying a fair premium. In fact, we show that irrespective of the size of the insured deposit base, banks would always want to take on additional leverage. If deposits are fairly priced, however, then imposing binding capital requirements makes banks too conservative. $^{2}$

Our model sheds light on some stylized facts in the banking literature. Most important, our theory speaks to the question of why banks are so highly levered. ${ }^{3}$ This is puzzling for various reasons. First, albeit many models assume a mechanical relationship between leverage and a bank's deposits, in practice banks typically take on additional debt over and above their deposit base. Second, even the safety net provided by deposit insurance and informal guarantees cannot fully account for their substantially higher leverage compared to non-financial corporations. While it is mainly large (money center) banks that benefit from such a safety net, other financial

\footnotetext{
1 The role of the loan officer is emphasized by Saunders and Allen (2002, p. 9), who write that "the credit decision is left to the local or branch lending officer or relationship manager. Implicitly, this person's expertise, subjective judgment, and his weighting of certain key factors are the most important determinants in the decision to grant credit."

2 We abstract from any externality a bank's failure could have on the financial system, in which case the normative benchmark would have to be adjusted. See Bhattacharya et al. (1998) for a discussion of the different objectives of banking regulation.

3 Flannery (1994, p. 321) notes that "financial firms' investment incentives are influenced by debt in the same way as any other firm's, yet they operate with unusually high leverage." He reports an equity-to-asset ratio of $6.5 \%$ for commercial banks in 1990 compared to a capital ratio of $55 \%$ for nonfinancial firms.
} 
intermediaries, such as finance companies, have similar capital ratios as banks do. ${ }^{4}$ Third, given the opaqueness of financial firms' assets and their potentially greater flexibility to make investments, one of the key disadvantages of leverage, namely, risk-shifting incentives, should weigh especially strong for financial firms (Kahn and Winton, 2004).

Our contribution is to provide a novel argument for why financial institutions should indeed have higher leverage than non-financial institutions. Our argument rests squarely on a "functional approach," namely, that an important function of banks is to make risky loans in a competitive environment. ${ }^{5}$

One limitation of our analysis is that we consider only one additional function of banks besides providing funds, namely, to conduct a credit risk analysis. Other models have focused on banks' incentives to monitor and recollect outstanding loans to derive an optimal mix between inside and outside finance (Besanko and Kanatas, 1996) or to explain the prevalence of (fragile) deposit contracts (Diamond and Rajan, 2000). ${ }^{6}$ Moreover, while we allow for both insured and uninsured deposits in our model, we merely treat them as another form of debt finance. In contrast, Diamond and Rajan (2000) and Calomiris and Kahn (1991) focus on specific features of deposit contracts, namely the sequential service constraint of demand deposits. Finally, our rationale for debt finance is different from arguments in the corporate finance literature, which typically link the choice of financing to problems of effort provision or adverse selection. (For applications to financial intermediaries, see, e.g., Diamond, 1984; Boyd and Prescott, 1986; Williamson, 1986 and, more recently, Allen et al., 2008.)

The rest of this paper is organized as follows. Section 2 introduces the model. Section 3 contains our main results. Section 4 presents comparative statics exercises. Section 5 concludes.

\section{The model}

In our basic model, we consider a single lender (the bank) and a penniless firm (the borrower). All parties are risk neutral. The borrower has an investment opportunity that requires a fixed capital outlay of $k>0$. The project generates either a zero cash flow or a positive cash flow $X>0$. The success probability depends on the project's type $\theta \in \Theta=\{l, h\}$ and is given by $p_{\theta}$. Instead of investing in the borrower's project, the bank can choose a safe investment opportunity, which bears the interest $r \geqslant 0$. Discounted with the interest rate $r$, the NPV of a type- $\theta$ project is thus $\eta_{\theta}:=\frac{1}{1+r} p_{\theta} X-k$. Only a type- $h$ project has strictly positive NPV.

Before making a loan, the bank conducts a credit risk analysis. Our model of credit risk analysis follows Inderst and Mueller $(2006,2007)$. The credit risk analysis generates additional valuable information, which we capture by a signal $s \in S=[0,1]$. A type- $\theta$ project generates a signal $s$ according to the atomless distribution function $F_{\theta}(s)$, which has a strictly positive density $f_{\theta}(s)$ over $s \in(0,1)$ and satisfies $f_{l}(0)>0, f_{h}(0)=0, f_{l}(1)=0$, and $f_{h}(1)>0$. We

\footnotetext{
4 In 2000 the ratio of equity capital to assets for finance companies was 10.9 percent compared to 8.5 percent for commercial banks (Saunders and Cornett, 2003). See also Dynan et al. (2002).

5 Diamond and Rajan (2000, p. 2431) also advocate a functional approach to banks' capital structure: "Most work on the subject extrapolates an answer from prior work on the capital structure of industrial firms. But bank assets and functions are not the same as those of industrial firms. [...] Therefore, to really understand the determinants of bank capital structure, we should start by modeling the essential functions banks perform, and then ask what role capital plays."

6 Gorton and Winton (2003, p. 61) argue that these models are “... most applicable to small banks, where issuing additional equity can substantially dilute top management's stake in the bank. In a large bank such as Citigroup, even a relatively small stock or option based stake can leave management with significant risk in absolute terms, and it seems less likely that issuing equity will significantly affect top management's' incentive to monitor loans effectively."
} 
specify that $F_{h}(s)$ dominates $F_{l}(s)$ in the sense of First-Order Stochastic Dominance (FOSD). Based on the only privately observed signal, posterior beliefs are given by

$$
\bar{\pi}_{\theta}(s):=\frac{\pi_{\theta} f_{\theta}(s)}{\sum_{\theta^{\prime} \in \Theta} \pi_{\theta^{\prime}} f_{\theta^{\prime}}(s)} \quad \text { for } \theta \in \Theta,
$$

where from FOSD of $F_{\theta}(s)$ we have that $\bar{\pi}_{h}(s)$ is strictly increasing in $s$. Together with $\eta_{l}<$ $0<\eta_{h}$ this yields a unique threshold $0<s_{F B}<1$ at which the NPV (conditional on the observed signal $s$ ) is just zero:

$$
\sum_{\theta \in \Theta} \bar{\pi}_{\theta}\left(s_{F B}\right) \eta_{\theta}=0
$$

It is therefore first-best efficient to approve the loan if $s>s_{F B}$ and to reject it is $s<s_{F B}$.

The contract that is offered by the bank before observing $s$, stipulates repayment of the principal plus interest $r_{B}$, though this will only occur in case of success. ${ }^{7}$ As noted in the Introduction, $s$ is supposed to capture the soft information and subjective judgment that influences a loan officer's credit decision, which is why the loan contract does not condition on. ${ }^{8}$ The bank's offer must also be sufficiently attractive to the borrower. More precisely, we require that the borrower's expected profits from approaching the bank must not fall short of a strictly positive reservation value $\bar{V}_{B}>0$.

We finally turn to the bank's own financing decision. For our purpose, it is sufficient to consider only two different sources of finance for the bank: equity $E$ and debt $D$, yielding total funds of $F:=E+D$. For simplicity, we stipulate that equity finance is provided by a single (owner-manager) investor. Neither form of financing is intrinsically cheaper as all investors have the opportunity cost $r$. Though we next impose some restrictions on the bank's financing, we will still be able to achieve the maximum feasible profits for the bank. In this sense, these restrictions are without loss of generality. As both the bank and individual investors can realize the safe return $r, F$ is not uniquely pinned down. We specify that $F=k$. (One way to endogenize this is to assume that there are some arbitrarily small costs of raising funds.) Given $F=k$, the bank's possible, verifiable cash flow realizations are (i) $y=k(1+r)$ if no loan was made, (ii) $y=\left(1+r_{B}\right) k$ if a successful loan was made, and (iii) $y=0$ if the loan went bad. The bank promises debtholders to repay the principal $D$ and the interest $D r_{D}$, whenever this is feasible. Consequently, equity has a levered stake with payout $\max \left\{0, y-D\left(1+r_{D}\right)\right\}$.

Though we specify that non-controlling investors receive a debt contract, in our model any optimal contract would give the controlling investor a levered position. Restricting attention to straight debt ensures that the incentives for risk-taking are fully captured by one variable, that is the level of debt financing $D$.

To summarize the description of the model, we (re-)state the various points on the timeline. First, the bank decides on which share of $k$ to raise through debt and which offers to make to potential debtholders $\left(r_{D}\right)$ and a potential borrower $\left(r_{B}\right)$. If the bank secures financing and if the

\footnotetext{
7 While we assume that there is commitment to the ex ante contract, contracts are also renegotiation-proof if $s$ is the bank's private information. Note also that the bank cannot "buy" the project, which is a standard assumption in contract theory. This assumption can be justified in our model by assuming that the credit risk analysis can also detect "fly-bynight operators" (Rajan, 1992; von Thadden, 1995), i.e., loan applicants without a real investment opportunity.

8 We could easily extend the model by introducing an additional verifiable signal, which could be incorporated into the loan contract. Note also that under the chosen formulation the bank's information is valuable as it can draw on its expertise in financing similar projects (see Manove et al., 2001). Consistent with this notion, Reid (1991) finds that bank-financed firms have higher survival rates than firms funded by family investors.
} 
borrower applies for a loan, the bank conducts the credit risk analysis and decides whether to approve the loan. ${ }^{9}$ If the loan is approved, the investment is made and payoffs are realized, while otherwise the investment is not undertaken.

\section{Main analysis}

\subsection{The credit decision of an all-equity financed bank}

In analogy to the first-best decision rule, the privately optimal credit decision of an all-equity financed bank $(D=0)$ follows again a cutoff rule. In case this cutoff is interior with $0<s_{E}^{*}<1$, it is defined by the requirement that at $s_{E}^{*}$ the bank is just indifferent between making the loan or investing in the safe asset:

$$
\sum_{\theta \in \Theta} \bar{\pi}_{\theta}\left(s_{E}^{*}\right) p_{\theta} k\left(1+r_{B}\right)=k(1+r) .
$$

It is convenient to specify that the bank approves the loan also in case of indifference, which is a zero-probability event.

The higher the loan rate $r_{B}$, the higher the likelihood that the loan is approved, i.e., the lower the cutoff $s_{E}^{*}$ in (3). As the borrower receives the residual payoff $X-k\left(1+r_{B}\right)$ in case a financed project was successful, the borrower's participation constraint becomes

$$
V_{B}:=\sum_{\theta \in \Theta} \pi_{\theta}\left[1-F_{\theta}\left(s_{E}^{*}\right)\right] p_{\theta} \frac{1}{1+r}\left[X-k\left(1+r_{B}\right)\right] \geqslant \bar{V}_{B} .
$$

The bank's program is now conceivably simple: Choose $r_{B}$ as high as possible while still satisfying the borrower's participation constraint (4). ${ }^{10}$ As $\bar{V}_{B}>0$, the bank can not extract all profits from the investment, implying that $k\left(1+r_{B}\right)<X$. As the bank provides, however, the full investment outlay $k$, it consequently does not break even at the first-best cutoff $s_{F B}$. Optimally, the bank then chooses a strictly higher cutoff $s_{E}^{*}>s_{F B}$. Furthermore, the wedge between $s_{E}^{*}$ and $s_{F B}$ increases the lower is the loan rate $r_{B}$, which in turn is the case the higher is the borrower's reservation value $\bar{V}_{B}$.

Proposition 1. The privately optimal credit decision of an all-equity financed bank is too conservative: $s_{E}^{*}>s_{F B}$. Moreover, an increase in the borrower's reservation value $\bar{V}_{B}$ raises the cutoff value $s_{E}^{*}$.

Proof. The result follows immediately from comparing (2) with (3).

A distinctive feature of our model is that we consider the credit risk analysis as a key step in the loan-originating process. Clearly, if the bank was not able to (privately) observe the signal $s$, the "underinvestment" problem of Proposition 1 would not arise. Moreover, as the bank does not own the project, it is natural to assume that $\bar{V}_{B}$ is strictly positive, i.e., the borrower can extract some of the profits from the investment. (See also Section 4.) Otherwise, i.e., if $\bar{V}_{B}=0$, the bank

\footnotetext{
${ }^{9}$ In what follows, we focus on the equilibrium where there is no co-ordination failure between the borrower and the bank's providers of finance. That is, we rule out the trivial equilibrium where one side does not accept the offer simply as it expects that also the other side does not accept.

10 Formally, the bank's objective function is $\sum_{\theta \in \Theta} \pi_{\theta}\left[1-F_{\theta}\left(s^{*}\right)\right]\left[p_{\theta} k\left(1+r_{B}\right)-k\right]+\sum_{\theta \in \Theta} \pi_{\theta} F_{\theta}\left(s^{*}\right) k(1+r)$.
} 
could charge the borrower an interest rate such that $k\left(1+r_{B}\right)=X$ and would subsequently make an efficient credit decision.

\subsection{Optimal capital structure}

If a levered bank invests in the safe asset, the respective payoff to equity equals $\max \{0$, $\left.k(1+r)-D\left(1+r_{D}\right)\right\}$. If a loan was made but the project was not successful, the payoff is zero. Finally, after financing a successful project the payoff is $\max \left\{0, k\left(1+r_{B}\right)-D\left(1+r_{D}\right)\right\}$. For $k\left(1+r_{B}\right) \leqslant D\left(1+r_{D}\right)$, equity would always realize zero, which we can safely rule out. The bank then optimally approves a loan, given the signal $s$, if

$$
\sum_{\theta \in \Theta} \bar{\pi}_{\theta}(s) p_{\theta} \max \left\{0, k\left(1+r_{B}\right)-D\left(1+r_{D}\right)\right\} \geqslant \max \left\{0, k(1+r)-D\left(1+r_{D}\right)\right\} .
$$

We have the following result.

Lemma 1. The credit decision of a levered bank is characterized as follows:

(i) If

$$
p_{l}\left[k\left(1+r_{B}\right)-D\left(1+r_{D}\right)\right] \geqslant \min \left\{0, k(1+r)-D\left(1+r_{D}\right)\right\},
$$

then the bank always approves the loan.

(ii) If

$$
p_{h}\left[k\left(1+r_{B}\right)-D\left(1+r_{D}\right)\right] \leqslant \min \left\{0, k(1+r)-D\left(1+r_{D}\right)\right\},
$$

then the bank never approves the loan.

(iii) In all other cases, the bank approves the loan if $s \geqslant s^{*}$ and rejects it if $s<s^{*}$, where $0<s^{*}<1$ solves

$$
\sum_{\theta \in \Theta} \bar{\pi}_{\theta}\left(s^{*}\right) p_{\theta}\left[k\left(1+r_{B}\right)-D\left(1+r_{D}\right)\right]=k(1+r)-D\left(1+r_{D}\right) .
$$

In a slight abuse of notation, we capture case (i) of Lemma 1, where the bank always approves the loan, by the cutoff signal $s^{*}=0$. Likewise, we capture case (ii), where the bank never approves the loan, by the cutoff signal $s^{*}=1 .^{11}$

To attract debtholders' funds, $r_{D}$ must satisfy their break-even constraint, which is the case if their expected repayment, $V_{D}$, satisfies

$$
\begin{aligned}
V_{D}:= & \sum_{\theta \in \Theta} \pi_{\theta}\left[1-F_{\theta}\left(s^{*}\right)\right] p_{\theta} \frac{1}{1+r} D\left(1+r_{D}\right) \\
& +\sum_{\theta \in \Theta} \pi_{\theta} F_{\theta}\left(s^{*}\right) \frac{1}{1+r} \max \left\{D\left(1+r_{D}\right), k(1+r)\right\} \\
\geqslant & D .
\end{aligned}
$$

Taking into account the interest rates $r_{B}$ and $r_{D}$, the value of equity is given by

$$
V_{E}:=\sum_{\theta \in \Theta} \pi_{\theta}\left[1-F_{\theta}\left(s^{*}\right)\right] p_{\theta} \frac{1}{1+r}\left[k\left(1+r_{B}\right)-D\left(1+r_{D}\right)\right]
$$

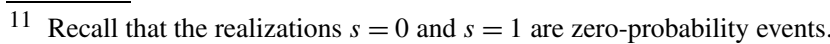




$$
+\sum_{\theta \in \Theta} \pi_{\theta} F_{\theta}\left(s^{*}\right) \frac{1}{1+r} \min \left\{0, k(1+r)-D\left(1+r_{D}\right)\right\} .
$$

Recall next that the bank has now three choice variables: (i) the loan rate, $r_{B}$, (ii) the interest rate, $r_{D}$, and (iii) what fraction of the total funds $k$ are raised through debt, $D$. The bank's constraints are the participation constraint of the borrower (4) and the participation constraint of debtholders (7). By optimality, the two constraints bind. Substituting the binding constraints (4) and (7) into (8), we obtain

$$
V_{E}-E=\sum_{\theta \in \Theta} \pi_{\theta} \eta_{\theta}\left[1-F_{\theta}\left(s^{*}\right)\right]-\bar{V}_{B},
$$

where we also used that $E+D=k$. Expression (9) is just a formal restatement of the fact that equity is the residual claimant, appropriating the full "franchise value" of the bank. Consequently, from an ex ante perspective it would be optimal for the bank to make the first-best credit decision: $s^{*}=s_{F B}$.

As we already know from the analysis of the all-equity case, the bank's ex post optimal credit decision may, however, differ from the ex ante optimal decision. In case of a levered bank, inspection of (6) reveals that $s^{*}$ strictly decreases with the amount that is owed to debtholders, i.e., with $D$ and $r_{D}$. To see why, observe first that $r_{D}>r$, i.e., that debtholders demand a risk premium. This follows immediately from the debtholders' break-even condition. From $r_{D}>r$, we next have immediately that

$$
k(1+r)-D\left(1+r_{D}\right)<E(1+r),
$$

implying that in a levered bank equity earns less than the (opportunity) costs of capital, $r$, if the bank invests in the safe asset. The higher is the promised repayment $D\left(1+r_{D}\right)$, the larger is this wedge between the return from the safe asset and the cost of capital. This wedge constitutes a countervailing force to the conservatism that we encountered with an all-equity bank. By adequately choosing its capital structure, the bank can balance these two forces so that its privately ex post optimal credit decision coincides with the ex ante optimal credit decision $s^{*}=s_{F B}$.

Proposition 2. The bank chooses a uniquely optimal level of debt $D^{*}>0$ so that its privately optimal credit decision coincides with the first-best optimal credit decision $s^{*}=s_{F B}$.

Proof. The result follows immediately from inserting the borrowers' participation constraint (4) and the debtholders' break-even constraint (7) into (6).

It is always possible to obtain $s^{*}=s_{F B}$ as by scaling up $D$, we can gradually decrease the bank's residual payoff in case it does not make a loan, $k(1+r)-D\left(1+r_{D}\right)$, which makes it increasingly unattractive to invest in the safe asset instead of making a loan. Formally, starting from $D=0$, which leads to some cutoff $s^{*}>s_{F B}$, we can continuously increase $D$ and thereby push down $s^{*}$ until reaching $s^{*}=s_{F B}$. Clearly, choosing an even higher leverage is not optimal.

By focusing on the function performed by sophisticated financial intermediaries such as banks, our approach may help to explain why financial institutions have much higher leverage than non-financial corporations. In contrast to non-financial corporations, financial institutions do not own the projects that they invest in. As we have seen in Proposition 1, this creates an underinvestment problem in the sense that financial institutions may be too conservative in their lending decisions. By levering up sufficiently, which increases their incentives to take on risks, financial institutions can mitigate this underinvestment problem. 


\section{Discussion}

\subsection{Regulation and deposit insurance}

\subsubsection{Bank capital regulation}

Leverage and capital adequacy requirements are among the most prominent instruments of banking regulation. The Basle Accord of 1988 prescribes a minimum ratio between a bank's capital and its risk-weighted assets. ${ }^{12}$ This requirement represents only a minimum standard and national regulators often impose additional requirements. For instance, the Bank of England watches banks' gearing ratio, defined as the ratio of deposits and external liabilities to a bank's capital and reserves. Also, the conditions under which banks can participate in the deposit insurance system are often contingent on banks' capital base (e.g., as prescribed in the US by the FDIC Improvement Act of 1991).

If regulatory constraints force banks to choose a lower than optimal level of leverage, the credit decision becomes inefficiently conservative. The proof of the following result is straightforward.

Corollary 1. If regulatory constraints force the bank to choose a lower than optimal debt level, its credit decision becomes inefficiently conservative. Precisely, given the constraint $D \leqslant \bar{D}<D^{*}$, the bank's optimal choice of debt is $\bar{D}$. The lower is $\bar{D}$, the greater is the gap between the bank's privately optimal cutoff $s^{*}$ and the first-best cutoff $s_{F B}$.

Corollary 1 shows that, next to curtailing banks' (short-run) potential to make new loans, binding capital requirements also have an indirect effect that follows directly from the main result in this paper. While more stringent capital requirements make banks safer they will, if they become binding, render the bank's lending policy inefficiently conservative. The reduction in the bank's (expected) loan volume that is brought about by imposing a binding constraint $D \leqslant \bar{D}$ is entirely due to the bank's lower risk appetite. In particular, as equity and debt financing are equally expensive, varying the level of debt does not affect the overall costs of financing.

\subsubsection{Deposit insurance}

Without regulation, the bank chooses just the right amount of leverage in our model. A key assumption underlying this result is that the bank's costs of funds fully reflect the (anticipated) riskiness of its loan book. In what follows, we deviate from this assumption and allow the bank to access insured deposits up to some (not too large) limit $d<k$. (For instance, $d$ may be determined by the size of the bank's retail network.)

The bank has now access to three sources of finance: insured deposits $D^{I} \leqslant d$, non-insured debt (e.g., non-insured deposits or subordinated debt) $D^{N}$, and equity $E$. The respective interest rates are denoted by $r_{D}^{I}$ and $r_{D}^{N}$. For simplicity, we assume that deposit insurance covers both the principal $D^{I}$ and the interest $D^{I} r_{D}^{I}$, implying that the costs of deposit finance do not respond at all to the bank's incentives to make risky loans. Also, we specify that insured deposits have absolute priority. For simplicity, we also ignore any insurance premium that the bank would have to pay when taking on insured deposits. What is important for our analysis is only that any such premium would not fully reflect the true risk of deposits.

12 The bank's capital base must reach at least $8 \%$ of total risk-weighted assets. Of this, $50 \%$ must be made up by core (or "Tier 1") capital, comprising mainly the bank's equity capital. 
The characterization of the optimal credit policy, which we now denote by $s_{D}^{*}$, is fully analogous to that in Lemma 1 . The only difference is that in case of success, the bank must now pay depositors the sum of $D^{I}\left(1+r_{D}^{I}\right)$ and $D^{N}\left(1+r_{D}^{N}\right)$. We next obtain for the value of equity

$$
\begin{aligned}
V_{E}= & \sum_{\theta \in \Theta} \pi_{\theta}\left[1-F_{\theta}\left(s_{D}^{*}\right)\right] p_{\theta} \frac{1}{1+r}\left[k\left(1+r_{B}\right)-D^{I}\left(1+r_{D}^{I}\right)-D^{N}\left(1+r_{D}^{N}\right)\right] \\
& +\sum_{\theta \in \Theta} \pi_{\theta} F_{\theta}\left(s_{D}^{*}\right) \frac{1}{1+r}\left[k(1+r)-D^{I}\left(1+r_{D}^{I}\right)-D^{N}\left(1+r_{D}^{N}\right)\right],
\end{aligned}
$$

and for the break-even constraint of non-insured debt

$$
\begin{aligned}
V_{D}^{N}:= & \sum_{\theta \in \Theta} \pi_{\theta}\left[1-F_{\theta}\left(s_{D}^{*}\right)\right] p_{\theta} \frac{1}{1+r} D^{N}\left(1+r_{D}^{N}\right) \\
& +\sum_{\theta \in \Theta} \pi_{\theta} F_{\theta}\left(s_{D}^{*}\right) \frac{1}{1+r} \max \left\{D^{N}\left(1+r_{D}^{N}\right), k(1+r)-D^{I}\left(1+r_{D}^{I}\right)\right\} \\
\geqslant & D^{N} .
\end{aligned}
$$

Importantly, the interest paid on insured deposits, $r_{D}^{I}$, does not depend on the anticipated cutoff $s_{D}^{*}$. We specify that $r_{D}^{I}=r$, though our results still hold as long as $r_{D}^{I}$ is not too high compared to $r$. Substituting $r_{D}^{I}=r$ and $r_{D}^{N}$ from the break-even constraint (7), we obtain from (11) that

$$
V_{E}-E=\sum_{\theta \in \Theta} \pi_{\theta}\left[1-F_{\theta}\left(s_{D}^{*}\right)\right] \eta_{\theta}-\bar{V}_{B}+\sum_{\theta \in \Theta} \pi_{\theta}\left[1-F_{\theta}\left(s_{D}^{*}\right)\right]\left(1-p_{\theta}\right) D^{I} .
$$

A comparison with (9) shows that the last line in (12) represents now the "gains" from raising insured deposits that are not fairly priced. $V_{E}$ is now maximized at an inefficiently low cutoff $s_{D}^{*}<s_{F B}$, as can be seen from differentiating (12) with respect to $s_{D}^{*}$ and evaluating the derivative at $s_{D}^{*}=s_{F B}$, which yields

$$
-\sum_{\theta \in \Theta} \pi_{\theta} f_{\theta}\left(s_{F B}\right)\left(1-p_{\theta}\right) D^{I}<0
$$

where for a type- $\theta$ loan the expected (discounted) transfer from the deposit insurance equals $D^{I}\left(1-p_{\theta}\right)$. At the optimal cutoff the sum of the NPV and the expected "subsidy" is zero. As the bank will optimally choose $D^{I}=d$, this is the case if

$$
\sum_{\theta \in \Theta} \bar{\pi}_{\theta}\left(s_{D}^{*}\right) \eta_{\theta}+d \sum_{\theta \in \Theta} \bar{\pi}_{\theta}\left(s_{D}^{*}\right)\left(1-p_{\theta}\right)=0 .
$$

Importantly, as long as $\bar{V}_{B}>0$ holds, then regardless of the size of the bank's insured deposit base $d$ it is clearly always optimal to take on additional non-insured debt. As noted in the Introduction, this is consistent with stylized facts. If, as postulated in many models, leverage implied excessive risk-taking, then, from an ex ante perspective, the bank would not want to take on additional debt that is fairly priced. Summarizing next our discussion and inspecting (13) and (14), we have the following result.

Proposition 3. If the bank has access to insured deposits, its credit decision under the optimal debt level is inefficiently lenient: $s_{D}^{*}=s_{D}<s_{F B}$, where the cutoff $s_{D}$ is decreasing in the amount of insured deposits $d$. Moreover, the bank always takes on additional non-insured debt over and above its insured deposits, i.e., $D^{N}>0$. 


\subsection{Comparative statics}

\subsubsection{Loan market competition}

The previous analysis has shown that the credit decision of an insufficiently levered bank is too conservative, because some of the proceeds from the investment must be shared with the borrower. This conservative bias is stronger the higher is the borrower's reservation value $\bar{V}_{B}$, which in turn is increasing in the degree of loan market competition. (If the bank is a monopolist and has all the bargaining power, then $\bar{V}_{B}=0$; otherwise it holds that $\bar{V}_{B}>0$, where $\bar{V}_{B}$ increases as loan market competition becomes more intense. See Inderst and Mueller, 2006, 2007 for a model of loan market competition in which $\bar{V}_{B}$ is endogenized along these lines.) If the bank can freely choose its debt level, it will then optimally adjust its leverage to accommodate changes in $\bar{V}_{B}$. The proof of the following result is straightforward.

Proposition 4. The optimal level of bank debt $D^{*}$ is strictly increasing in the borrower's reservation value $\bar{V}_{B}$, and thus in the intensity of loan market competition.

Proposition 4 also implies that the optimal leverage ratio, $D /\left(\bar{V}_{E}+D\right)$, is increasing in $\bar{V}_{B}$. This holds for two reasons. First, by Proposition 4 the optimal debt level increases with $\bar{V}_{B}$. Second, an increase in $\bar{V}_{B}$ implies lower net profits for equity, $V_{E}-E$ (cf. expression (9)). Consequently, the numerator $(D)$ is strictly increasing in $\bar{V}_{B}$, while the denominator $\left(V_{E}+D\right)$ is strictly decreasing. ${ }^{13}$

Proposition 4 has the following straightforward empirical implication.

Corollary 2. A decrease in the bank's profitability due to more intense loan market competition leads to an increase in the bank's optimal debt level and leverage ratio.

The negative association between profitability and leverage, as postulated in Corollary 2, contrasts with the predictions of standard capital structure theories in corporate finance. Based on the notion of financial distress, it has been argued that more profitable firms can sustain higher levels of (tax-advantageous) debt financing. In a recent study, Gropp and Heider (2006) examine the capital structures of 200 large banks. Consistent with Corollary 2, they find that higher profitability is associated with lower leverage.

\subsubsection{Leverage and risk-taking}

If the fundamentals of potential borrowers, as well as those of the bank's screening technology, remain constant, then our model predicts that there should be no systematic relation between leverage and risk-taking, at least not if the bank's capital structure remains "in equilibrium." To illustrate this formally, we consider again the comparative statics in the degree of loan market competition.

\footnotetext{
13 Interestingly, by looking at the market pressure from the "liability side" instead of the "asset side," as in our model, Flannery and Rangan (2004) paint a different picture than we do in Proposition 4. They argue that the capital build-up of US banks in the 1990s was a response to more risk-sensitive pricing of banks' own financing. Incidentally, in an historic perspective, the capital base of US banks has substantially eroded over the past decades. Along with other authors, Berger et al. (1995) relate this to both explicit and implicit guarantees for banks' depositors. According to Proposition 4, a decline in banks' capital ratios could also come from an increase in loan market competition.
} 
Note first that the probability of loan default remains constant at

$$
\frac{\sum_{\theta \in \Theta} \pi_{\theta}\left[1-F_{\theta}\left(s_{F B}\right)\right]\left(1-p_{\theta}\right)}{\sum_{\theta \in \Theta} \pi_{\theta}\left[1-F_{\theta}\left(s_{F B}\right)\right]} .
$$

Likewise, using a different measure of riskiness that is commonly used in the empirical literature, the variation in the bank's return to equity remains unchanged. To see this, note that the realized return of an approved loan that is successful is

$$
\frac{\left[k\left(1+r_{B}\right)-D\left(1+r_{D}\right)\right]-V_{E}}{V_{E}},
$$

while if the bank invests in the safe asset, the return equals

$$
\frac{\left[k(1+r)-D\left(1+r_{D}\right)\right]-V_{E}}{V_{E}} .
$$

Furthermore, the realized return for an approved but ultimately bad loan is always $-100 \%$, while by definition of $V_{E}$ the expected return to equity equals $r$. As leverage adjusts to ensure that $s^{*}=s_{F B}$ remains unchanged, we have from (6) in Lemma 1 that also the ratio

$$
\frac{k\left(1+r_{B}\right)-D\left(1+r_{D}\right)}{k(1+r)-D\left(1+r_{D}\right)}
$$

remains unchanged. From these observations, it follows immediately that both (16) and (17) must remain constant.

Corollary 3. If the bank's leverage adjusts optimally to changes in loan market competition, then both the bank's loan default rate as well as the level and variance of returns to equity remain unchanged.

While from Corollary 3 there should thus ceteris paribus not be a systematic relationship between leverage and risk, such a systematic negative relationship can, however, arise if exogenous changes relate to the fundamentals of projects or the bank's screening technology. Before showing this formally in the subsequent sections, it is convenient to relate this already now to the extant literature.

Existing models as well as empirical evidence paint a mixed picture of the relationship between leverage and risk. It is probably fair to say that the prevalent view associates higher leverage with more risk-taking (e.g., Flannery, 1989; Gennotte and Pyle, 1991). However, if banks are hit by shocks that erode their capital base, and if asymmetric information makes it costly to raise fresh equity (e.g., Stein, 1998), a negative correlation between leverage and the creation of new loans arises. This holds, in particular, if the bank's regulatory capital requirement binds, and if the bank has a profitable franchise (see Marcus, 1984).

Our perspective is different as we presume that leverage can adjust optimally and is thus neither hard-wired to deposits nor too costly to change. If, as in Corollary 3, the borrower fundamentals remain unchanged, then we should expect no systematic relationship between lending and risk-taking. In contrast, as we show next, we should expect a negative relationship if the empirical analysis allows to distinguish among banks' ability to make less risky loans, e.g., because there is cross-sectional variation in the pool of potential borrowers or the banks' ability to screen borrowers. Empirically, a negative correlation is obtained by Demsetz et al. (1996) and, more recently, by Gropp and Heider (2006), whereas Kwan and Eisenbeis (1997) find the opposite relationship (see also the discussion in Berger et al., 1995). 


\subsubsection{Access to borrowers with different risk profiles}

We now allow for two payoffs $x_{l}$ and $x_{h}$ satisfying $0 \leqslant x_{l}<k<x_{h}$. We analyze the implications of raising the low payoff $x_{l}$ while keeping the mean fixed by simultaneously lowering $x_{h}$ (mean-preserving spread). Setting $p_{l}=0$, we thus require that $x_{l}$ and $x_{h}$ adjust jointly such that $x_{l}\left(1-p_{h}\right)+x_{h} p_{h}$ remains constant.

As $x_{l}$ increases, the claim of the bank's unsecured debtholders becomes less risky. Consequently, unsecured debtholders will demand a lower risk premium $r_{D}-r$. As we argued previously, it is precisely this risk premium that exerts a countervailing force to the bank's conservatism, which is why the optimal debt level has to increase. Given that the value of the bank's franchise, $V_{E}+D$, remains constant under the considered mean-preserving spread, this also implies that the bank's leverage ratio, $D /\left(D+V_{E}\right)$, increases.

Proposition 5. As the bank's borrower pool becomes safer, the bank's optimal debt level and leverage ratio increase.

\section{Proof. See Appendix A.}

\subsubsection{Variation in banks' ability to screen borrowers}

To obtain a continuous yet simple measure of the bank's informational advantage vis-à-vis other lenders, we assume it is now only with probability $0<q \leqslant 1$ that the bank has a more precise estimate of the borrower's probability of success. Our previous analysis corresponds to the case where $q=1$, while changes in $q$ capture changes in the bank's ability to screen borrowers.

As we want to allow for the case where $q$ is close to zero, which reduces the value added that the bank can generate through its more informative signal $s, \sum_{\theta \in \Theta} \pi_{\theta} \eta_{\theta}$ clearly represents an upper limit for the borrower's reservation value $\bar{V}_{B}$. We thus set $\bar{V}_{B}=\sum_{\theta \in \Theta} \pi_{\theta} \eta_{\theta} \cdot{ }^{14}$

Proposition 6. As the informativeness of the bank's credit risk analysis improves, i.e., as $q$ increases, the bank's optimal debt level increases. On the other side, as $q$ approaches zero, the optimal debt level remains bounded away from zero.

\section{Proof. See Appendix A.}

The intuition for Proposition 6 is straightforward. The more precise the bank's information is, the more certain can the bank's debtholders be that a loan is given only if the success probability is high. Consequently, for a given level of debt, the required risk premium $r_{D}-r$ decreases. To ensure that the bank implements the efficient credit decision in case it observes an informative signal, it is then necessary to increase the debt level $D$.

\subsubsection{Diversified versus focused loan portfolio}

In our model, the bank can choose between a single risky asset, namely, a loan, and a safe asset. This choice between a single risky asset and a safe asset is common to risk-shifting models, including applications to banking. ${ }^{15}$ In banking, in particular, there is indeed much historical and

$\overline{14}$ As shown in Inderst and Mueller (2007), $\bar{V}_{B}$ can be generated from competing offers of other, non-informed lenders.

15 For example, Hellmann et al. (2000) assume that a bank can choose between a prudent asset, yielding some return $\alpha$, and a gambling asset, yielding an uncertain return equal to $\gamma$ with probability $\theta$ and equal to $\beta$ with probability $1-\theta$. 
empirical evidence suggesting that risk-shifting is an important issue (e.g., the S\&L crises in the 1990s). As banks hold large loan portfolios in practice, albeit not perfectly diversified ones, it is important to check the robustness of our results for the case where the bank can make $N>1$ new loans.

Note first that if the bank can make $N>1$ new loans, its optimal choice is to set a common credit policy $s^{*}$ that is applied (e.g., by its loan officers) to each simultaneous loan application. The case where the $N$ loans are perfectly positively correlated is trivial; the results are identical to the single-loan case analyzed before. Consider therefore the other polar case where the $N$ loans are uncorrelated (in terms of realization of the underlying state $\theta$ ).

Proposition 7. If the bank faces $N>1$ independent loan opportunities with uncorrelated prospects, then, for all finite $N$, it remains optimal to raise strictly positive debt to implement the efficient credit policy $s^{*}=s_{F B}$.

\section{Proof. See Appendix A.}

That $s^{*}=s_{F B}$ is still optimal, regardless of $N$, is immediate given that the bank is the residual claimant, once the binding constraints for borrowers and debtholders have been substituted into the bank's objective function. That positive leverage is necessary is also immediate as the choice of $N>1$ does not fundamentally alter the basic "underinvestment problem" that makes the bank too conservative in case $D=0$ and $\bar{V}_{B}>0$ hold. Finally, that $s^{*}=s_{F B}$ is also feasible follows intuitively from the observation that for very high leverage the bank will "overshoot" and become too lenient with $s^{*}<s_{F B}$. To see this, take the extreme case where the total repayment obligation $D\left(1+r_{D}\right)$ is (arbitrarily) close to $N k\left(1+r_{B}\right)$. In particular, $D\left(1+r_{D}\right)$ would then exceed the sum of $(N-1) k\left(1+r_{B}\right)$ and $k(1+r)$. Consequently, banks' equityholders would themselves realize a positive payoff only if all $N$ loans are approved (and ultimately successful).

As a comparative analysis of the optimal leverage in $N$ proves too be rather intricate, we confine ourselves to a comparison of the single-loan case with the case where $N=2$.

Proposition 8. The bank's optimal leverage ratio is strictly higher for $N=2$ independent loan opportunities than if $N=1$.

\section{Proof. See Appendix A.}

To understand why the banks' leverage ratio increases when switching from $N=1$ to $N=2$, note first that (as formalized in Proposition 8) the efficient credit policy $s^{*}=s_{F B}$, which the bank implements via its choice of leverage, is not affected by $N$. This simplifies the analysis, as it implies that $r_{B}$ remains also unchanged. Recall next that the bank's (additional) risk-taking incentives due to leverage depend on the difference $r_{D}-r>0$. Suppose the bank only raised twice the amount of debt for $N=2$ compared to what is optimal for $N=1$, implying that the leverage ratio would remain unchanged. Then, due to a standard "co-insurance" effect (cf. Lewellen, 1971), debtholders would break even with a smaller $r_{D}$. To then still ensure that the

On the other hand, some of the theoretical literature on banking rests on the notion that banks hold a well-diversified portfolio of loans (e.g., Diamond, 1984). 
efficient credit policy $s^{*}=s_{F B}$ is implemented, the bank must raise more than twice the amount of debt. ${ }^{16}$

To the extent that large banks have more diversified loan portfolios, Proposition 8 has implications for the relation between bank size and leverage. Accordingly, large banks should then have higher leverage ratios than small banks, which seems to be consistent with much, though not all, of the available empirical evidence (see Gambacorta and Mistrulli, 2004 for a recent study of Italian banks). Of course, this may also follow from other reasons, including smaller banks' higher costs of raising fresh capital.

There is also some evidence that large banks make riskier loans. Together with a higher leverage, this would seem to contradict the prediction in Proposition 5. However, what drives the negative correlation between leverage and risk-taking in Proposition 5 is a (cross-sectional) difference in the pool of potential borrowers. Instead, large banks may differ in other aspects that may explain why they take on more risk. For example, they may have more sophisticated riskmanagement techniques, as in Demsetz and Strahan (1997).

\section{Conclusion}

We present a novel theory of banks' optimal capital structure. We show how competition for borrowers leads to an "underinvestment problem," unless banks are levered up sufficiently. Our key assumption is that banks are sophisticated lenders, who generate valuable information when analyzing the creditworthiness of the borrower's investment project. Absent regulatory interference, banks choose the first-best level of debt financing. On the other side, banks lever up excessively and over-expand their loan books in the presence of insured deposit finance without adequately priced risk premium.

One of the key contributions of this papers is thus to question the presumption that without regulation any positive leverage leads to excessive risk-taking by banks. In contrast, we show that leverage is necessary to provide first-best incentives for risk-taking. The paper also develops a theory of optimal bank capital structure that is both specific to financial institutions and that is driven entirely by the bank's function to make new risky loans. The first feature is important as it makes a qualitative difference between financial and non-financial institutions, which could in turn explain some of the differences in their respective leverage. The second feature is also attractive as banks' leverage does not seem to be completely hard-wired to their level of deposits.

We also show that, according to our theory, leverage should be positively correlated with the degree of competition on the loan market and thus negatively correlated with their franchise value. However, if banks optimally adjust their leverage then this should not have an impact on their riskiness. Leverage adjusts only sufficiently so as to still ensure that banks have first-best incentives to take on risky loans.

\footnotetext{
16 It should be noted that, in our setting, the bank cannot invest more than $k$ in a single project. Otherwise, by allowing the bank to pick the best of two investment opportunities, the expansion of its business might more than double its overall (franchise) value. Moreover, debtholders and equityholders would in this case always agree on the optimal allocation of funds. This is different from Kahn and Winton (2004), where different subsidiaries of a conglomerate have different risk-return profiles.
} 


\section{Acknowledgments}

We are grateful to the editor, Elu von Thadden, two anonymous referees, David Webb, Anthony Saunders, and seminar participants at the London School of Economics, Bank of England, and INSEAD for helpful comments and suggestions. Inderst gratefully acknowledges financial support from the Financial Markets Group at the London School of Economics.

\section{Appendix A. Proofs}

Proof of Proposition 5. From the definition of the first-best credit decision it must now hold that

$$
k(1+r)=\sum_{\theta \in \Theta} \bar{\pi}_{\theta}\left(s_{F B}\right)\left[p_{\theta} x_{h}+\left(1-p_{\theta}\right) x_{l}\right] .
$$

Observe next that in order to achieve $s^{*}=s_{F B}$, debt must be risky: $D\left(1+r_{D}\right)>x_{l}$. This allows to still apply Lemma 1 for the definition of $s^{*}$. Rewriting the borrower's participation constraint (3) we also have that

$$
k\left(1+r_{B}\right)=\frac{\sum_{\theta \in \Theta} \pi_{\theta}\left[1-F_{\theta}\left(s^{*}\right)\right] p_{\theta} X-\bar{V}_{B}(1+r)}{\sum_{\theta \in \Theta} \pi_{\theta}\left[1-F_{\theta}\left(s^{*}\right)\right] p_{\theta}} .
$$

Substituting (A.1) and the definition of $s^{*}$ from Lemma 1 into (A.2), we can then solve for

$$
D\left(1+r_{D}\right)=x_{l}+\frac{\sum_{\theta \in \Theta} \bar{\pi}_{\theta}\left(s_{F B}\right) p_{\theta}}{1-\sum_{\theta \in \Theta} \bar{\pi}_{\theta}\left(s_{F B}\right) p_{\theta}} \frac{(1+r) \bar{V}_{B}}{\sum_{\theta \in \Theta} \pi_{\theta}\left[1-F_{\theta}\left(s_{F B}\right)\right] p_{\theta}} .
$$

This can finally be substituted into the break-even requirement of debtholders

$$
\begin{aligned}
D(1+r)= & D\left(1+r_{D}\right)\left[\sum_{\theta \in \Theta} \pi_{\theta}\left[1-F_{\theta}\left(s_{F B}\right)\right] p_{\theta}+\sum_{\theta \in \Theta} \pi_{\theta} F_{\theta}\left(s_{F B}\right)\right] \\
& +x_{l} \sum_{\theta \in \Theta} \pi_{\theta}\left[1-F_{\theta}\left(s_{F B}\right)\right]\left(1-p_{\theta}\right),
\end{aligned}
$$

to finally

$$
D(1+r)
$$

Consequently, an increase in $x_{l}$ requires an increase in $D$ by $x_{l} /(1+r)$.

Proof of Proposition 6. We show first that under the optimal contract the bank will approve the loan if it does not observe an informative signal. This holds if

$$
\sum_{\theta \in \Theta} \pi_{\theta} p_{\theta}\left[k\left(1+r_{B}\right)-D\left(1+r_{D}\right)\right]>k(1+r)-D\left(1+r_{D}\right),
$$

which after substituting the definition of $s^{*}$ from Lemma 1 together with $s^{*}=s_{F B}$ is satisfied in case $\bar{\pi}_{h}\left(s_{F B}\right)>\pi_{h}$. This follows finally from $\bar{V}_{B}=\sum_{\theta \in \Theta} \pi_{\theta} \eta_{\theta}>0$ and $\sum_{\theta \in \Theta} \bar{\pi}_{\theta}\left(s_{F B}\right) \eta_{\theta}=0$. 
For general $q$, the participation constraint of borrowers becomes

$$
\sum_{\theta \in \Theta} \pi_{\theta} p_{\theta}\left[1-q F_{\theta}\left(s_{F B}\right)\right] \frac{1}{1+r}\left[X-k\left(1+r_{B}\right)\right] \geqslant \bar{V}_{B}=\sum_{\theta \in \Theta} \pi_{\theta} \eta_{\theta},
$$

while the break-even requirement for debtholders becomes

$$
\sum_{\theta \in \Theta} \pi_{\theta}\left[q F_{\theta}\left(s^{*}\right)+p_{\theta}\left[1-q F_{\theta}\left(s_{F B}\right)\right]\right] \frac{1}{1+r} D\left(1+r_{D}\right) \geqslant D
$$

By optimality these are satisfied with equality. Together with the definition of $s^{*}$ from Lemma 1 , we can stepwise solve out for $r_{B}$ and $r_{D}$ to finally obtain

$$
D=\left[\sum_{\theta \in \Theta} \pi_{\theta} \eta_{\theta}\right]\left[\frac{\sum_{\theta \in \Theta} \bar{\pi}_{\theta}\left(s_{F B}\right) p_{\theta}}{1-\sum_{\theta \in \Theta} \bar{\pi}_{\theta}\left(s_{F B}\right) p_{\theta}}\right]\left[\frac{\sum_{\theta \in \Theta} \pi_{\theta} p_{\theta}+q \sum_{\theta \in \Theta} \pi_{\theta} F_{\theta}\left(s_{F B}\right)\left(1-p_{\theta}\right)}{\sum_{\theta \in \Theta} \pi_{\theta} p_{\theta}-q \sum_{\theta \in \Theta} \pi_{\theta} F_{\theta}\left(s_{F B}\right) p_{\theta}}\right],
$$

which is thus strictly increasing in $q$. Finally, note that at the limit where $q \rightarrow 0$ we obtain that

$$
D=\left[\sum_{\theta \in \Theta} \pi_{\theta} \eta_{\theta}\right]\left[\frac{\sum_{\theta \in \Theta} \bar{\pi}_{\theta}\left(s_{F B}\right) p_{\theta}}{1-\sum_{\theta \in \Theta} \bar{\pi}_{\theta}\left(s_{F B}\right) p_{\theta}}\right]>0 .
$$

Proof of Proposition 7. It is convenient to reformulate the bank's program as follows. Suppose the bank has chosen for $n=1, \ldots, N-1$ the symmetric standard $s_{n}^{*}=s^{*}$. We focus next on the optimal choice of $s_{N}^{*}$. To derive the expected payoffs, we make the dependency on the parameters $\omega=(n, m)$ explicit, where $n$ will denote the number of approved applications (out of $N-1$ ) and $m$ the number of ultimately successful projects. For the respective trinomial distribution we obtain

$$
\begin{aligned}
\hat{\rho}(\omega):= & \frac{(N-1) !}{(N-1-n) ! m !(n-m) !} \\
& \cdot\left(\sum_{\theta \in \Theta} \pi_{\theta} F_{\theta}\left(s^{*}\right)\right)^{N-1-n}\left(\sum_{\theta \in \Theta} \pi_{\theta}\left(1-F_{\theta}\left(s^{*}\right)\right) p_{\theta}\right)^{m} \\
& \cdot\left(\sum_{\theta \in \Theta} \pi_{\theta}\left(1-F_{\theta}\left(s^{*}\right)\right)\left(1-p_{\theta}\right)\right)^{n-m},
\end{aligned}
$$

while the respective payoff from the $N-1$ applications equals

$$
\widehat{\Pi}(\omega):=(N-1-n) k(1+r)+m k\left(1+r_{B}\right) .
$$

It is first convenient to consider the case of an all-equity financed bank such that

$$
V_{E}=\sum_{\varpi} \hat{\rho}(\omega)\left(\begin{array}{c}
\sum_{\theta \in \Theta} \pi_{\theta} F_{\theta}\left(s_{N}^{*}\right)(\widehat{\Pi}(\omega)+k(1+r)) \\
+\sum_{\theta \in \Theta} \pi_{\theta}\left(1-F_{\theta}\left(s_{N}^{*}\right)\right)\left(1-p_{\theta}\right) \widehat{\Pi}(\omega) \\
+\sum_{\theta \in \Theta} \pi_{\theta}\left(1-F_{\theta}\left(s_{N}^{*}\right)\right) p_{\theta}\left(\widehat{\Pi}(\omega)+k\left(1+r_{B}\right)\right)
\end{array}\right) .
$$

Differentiating with respect to $s_{N}^{*}$ yields

$$
\frac{\partial V_{E}}{\partial s_{N}^{*}}=\sum_{\varpi} \hat{\rho}(\omega)\left(\begin{array}{c}
\sum_{\theta \in \Theta} \pi_{\theta} f_{\theta}\left(s_{N}^{*}\right)(\widehat{\Pi}(\omega)+k(1+r)) \\
-\sum_{\theta \in \Theta} \pi f_{\theta}\left(s_{N}^{*}\right)\left(1-p_{\theta}\right) \widehat{\Pi}(\omega) \\
-\sum_{\theta \in \Theta} \pi_{\theta} f_{\theta}\left(s_{N}^{*}\right) p_{\theta}\left(\widehat{\Pi}(\omega)+k\left(1+r_{B}\right)\right)
\end{array}\right),
$$


which can finally be transformed to obtain the first-order condition

$$
\sum_{\varpi} \hat{\rho}(\omega)\left[k(1+r)-\sum_{\theta \in \Theta} \bar{\pi}_{\theta}\left(s_{N}^{*}\right) p_{\theta} k\left(1+r_{B}\right)\right]=0 .
$$

Given quasiconcavity in $s_{N}^{*}$, we have from inspection of (A.4) a unique solution $s_{N}^{*}>s_{F B}$ as long as $k\left(1+r_{B}\right)<X$. Introducing next positive leverage, we use $\widehat{D}:=D\left(1+r_{D}\right)$. As previously, we obtain $\partial V_{E} / \partial s_{N}^{*}$ as in (A.3), which from symmetry and using total differentiation yields then $\mathrm{d} V_{E} / \mathrm{d} s^{*}=N\left(\partial V_{E} / \partial s_{N}^{*}\right)$, evaluated at $s_{N}^{*}=s^{*}$. From this we subsequently obtain in analogy to (A.4) the first-order condition

$$
\sum_{\omega} \hat{\rho}(\omega)\left[\begin{array}{c}
\max \{0, \widehat{\Pi}(\omega)+k(1+r)-\widehat{D}\}-\max \{0, \widehat{\Pi}(\omega)-\widehat{D}\} \\
-\sum_{\theta \in \Theta} \bar{\pi}_{\theta}\left(s_{N}^{*}\right) p_{\theta}\left(\begin{array}{c}
\max \left\{0, \widehat{\Pi}(\omega)+k\left(1+r_{B}\right)-\widehat{D}\right\} \\
-\max \{0, \widehat{\Pi}(\omega)-\widehat{D}\}
\end{array}\right)
\end{array}\right]=0 .
$$

As regardless of $\omega$ the term in square brackets in (A.4) is strictly decreasing in $s_{N}^{*}$, we have from strict quasiconcavity of the objective function a unique solution for $s_{N}^{*}$. (Again, we have to finally set $s_{N}^{*}=s^{*}$.)

From an ex ante perspective leverage is again optimally chosen so as to ensure that the ex post optimal choice satisfies $s^{*}=s_{F B}$. (Formally, this is again obtained from substituting the binding participation constraints for debtholders and the borrower into $V_{E}$.) To see that a solution $0<\widehat{D}<N k\left(1+r_{B}\right)$ exists at which (A.5) is satisfied for $s^{*}=s_{N}^{*}=s_{F B}$, we can substitute first for $k\left(1+r_{B}\right)$ from the borrower's binding participation constraint (4), which is independent of $N$. Observe next that the left-hand side of (A.5) is continuous in $\widehat{D}$ and from (A.4) strictly positive at $\widehat{D}=0$. As for $\widehat{D}=N k\left(1+r_{B}\right)$ it is exactly zero, it is sufficient to show that for all $\widehat{D}$ in the left-side neighborhood of $\widehat{D}=N k\left(1+r_{B}\right)$ (i.e., for $\left.\widehat{D}=N k\left(1+r_{B}\right)-\varepsilon\right)$ it is strictly negative. (Note also that for all $\widehat{D}<N k\left(1+r_{B}\right)$ the optimal cutoff $s_{N}^{*}$ is indeed uniquely determined given that, as noted above, the term in square brackets in (A.4) is strictly decreasing in $s_{N}^{*}$.) As in this case the only positive term on the left-hand side of (A.5) is that where $\widehat{\Pi}(\omega)=(N-1) k\left(1+r_{B}\right)$ and where, in addition, $k\left(1+r_{B}\right)$ is realized from project $N$, the derivative w.r.t. $\widehat{D}$ is given by $\hat{\rho}(\omega) \sum_{\theta \in \Theta} \bar{\pi}_{\theta}\left(s_{F B}\right) p_{\theta}>0$.

To finally compute from $\widehat{D}$ both $D$ and $r_{D}$, we can use $\widehat{D}=D\left(1+r_{D}\right)$ together with the break-even constraint for borrowers. To write out the latter in the shortest possible way, define for some $\omega=(n, m)$, where now $0 \leqslant m \leqslant n \leqslant N$,

$$
\Pi(\omega):=(N-n) k(1+r)+m k\left(1+r_{B}\right)
$$

as well as

$$
\begin{aligned}
\rho(\omega):= & \frac{N !}{(N-n) ! m !(n-m) !} \\
& \cdot\left(\sum_{\theta \in \Theta} \pi_{\theta} F_{\theta}\left(s_{F B}\right)\right)^{N-n}\left(\sum_{\theta \in \Theta} \pi_{\theta}\left(1-F_{\theta}\left(s_{F B}\right)\right) p_{\theta}\right)^{m} \\
& \cdot\left(\sum_{\theta \in \Theta} \pi_{\theta}\left(1-F_{\theta}\left(s_{F B}\right)\right)\left(1-p_{\theta}\right)\right)^{n-m} .
\end{aligned}
$$

The binding break-even constraint then becomes

$$
\sum_{\omega \text { with } 0 \leqslant m \leqslant n \leqslant N} \frac{1}{1+r} \min \{\Pi(\omega), \widehat{D}\} \rho\left(n, m, N ; s^{*}\right)=D .
$$


Proof of Proposition 8. Denote by $D^{*}$ the level of debt financing that implements the first-best credit decision if $N=1$. Holding $s^{*}=s_{F B}$ fixed, note that the borrower's participation constraint and thus $r_{B}$ are independent of $N$. To show that $D>2 D^{*}$ is optimal in case $N=2$ we argue to a contradiction. For this we suppose first that $D=2 D^{*}$ and that debtholders would still assume (wrongly) that the bank chooses $s^{*}=s_{F B}$.

We denote the interest rate at which debtholders break even originally by $r_{D}^{*}$. and by $r_{D}^{* *}$ the corresponding interest rate for $N=2, D=2 D^{*}$, and still $s^{*}=s_{F B}$. We show that $r_{D}^{* *}<r_{D}^{*}$. Given that the argument involves some lengthy algebraic transformations, we restrict a detailed analysis to the case where $2 D^{*}\left(1+r_{D}^{*}\right) \leqslant k(1+r)$. The other feasible cases, where the "coinsurance" effect is smaller but still present, are those where $k(1+r)<2 D^{*}\left(1+r_{D}^{*}\right) \leqslant k\left(1+r_{B}\right)$ and where $2 D^{*}\left(1+r_{D}^{*}\right)>k\left(1+r_{B}\right)$.

For $N=1$ we decompose $V_{E}$ into two terms such that $V_{E}(1+r)=A_{1}-B_{1}$. Here, $A_{1}$ denotes the expected cash flow to the bank, while $B_{1}$ denotes the expected payoff to debtholders. While generally we found it more instructive to work with the primitives of the model, namely the distribution of types $\theta$, it is now more tractable to introduce some additional notation. For this we denote the ex ante distribution over the subsequently observed signals by $G(s)$ with density $g(s):=\sum_{\theta \in \Theta} \pi_{\theta} f_{\theta}(s)$ and the conditional success probability after observing $s$ by $p(s):=$ $\sum_{\theta \in \Theta} \bar{\pi}_{\theta} p_{\theta}$. With this notational change, we now have

$$
A_{1}=k(1+r) G\left(s^{*}\right)+k\left(1+r_{B}\right)\left(1-G\left(s^{*}\right)\right) p_{\emptyset},
$$

where

$$
p_{\emptyset}:=\frac{\int_{s^{*}}^{1} p(s) g(s) \mathrm{d} s}{1-G\left(s^{*}\right)} .
$$

Differentiation of $A_{1}$ yields after some transformations that

$$
\frac{\mathrm{d} A_{1}}{\mathrm{~d} s^{*}}=g\left(s^{*}\right) k\left[\left(p_{\emptyset}-p\left(s^{*}\right)\right)-\left(r_{B}-r\right)\right],
$$

while for $B_{1}$ with

$$
B_{1}=D^{*}\left(1+r_{D}^{*}\right)\left[G\left(s^{*}\right)+\left(1-G\left(s^{*}\right)\right) p_{\emptyset}\right]
$$

we obtain

$$
\frac{\mathrm{d} B_{1}}{\mathrm{~d} s^{*}}=D^{*}\left(1+r_{D}^{*}\right) g\left(s^{*}\right)\left(1+p\left(s^{*}\right)\right) .
$$

We can also use that

$$
D^{*}\left(1+r_{D}^{*}\right)=\frac{D^{*}(1+r)}{1-\left(1-G\left(s^{*}\right)\right)\left(1-p_{\emptyset}\right)} .
$$

Turn now to the case with $N=2$, where $V_{E}(1+r)=A_{2}-B_{2}$ with

$$
\begin{aligned}
A_{2}= & k(1+r)\left[2 G^{2}\left(s^{*}\right)+2 G\left(s^{*}\right)\left(1-G\left(s^{*}\right)\right)\right] \\
& +k\left(1+r_{B}\right)\left[2\left(1-G\left(s^{*}\right)\right)^{2} p_{\emptyset}+2 G\left(s^{*}\right)\left(1-G\left(s^{*}\right)\right) p_{\emptyset}\right]
\end{aligned}
$$

and

$$
B_{2}=2 D^{*}\left(1+r_{D}^{* *}\right)\left[1-\left(1-G\left(s^{*}\right)\right)^{2}\left(1-p_{\emptyset}\right)^{2}\right] .
$$


After some transformations we have

$$
\frac{\mathrm{d} A_{2}}{\mathrm{~d} s^{*}}=2 g\left(s^{*}\right) k\left[\left(p_{\emptyset}-p\left(s^{*}\right)\right)-\left(r_{B}-r\right)\right]
$$

and

$$
\frac{\mathrm{d} B_{2}}{\mathrm{~d} s^{*}}=4 D^{*}\left(1+r_{D}^{* *}\right)\left(1-G\left(s^{*}\right)\right)\left(1-p_{\emptyset}\right) g\left(s^{*}\right)\left(1+p\left(s^{*}\right)\right),
$$

while by definition of $r_{D}^{* *}$ we can also use that

$$
D^{*}\left(1+r_{D}^{* *}\right)=\frac{D^{*}(1+r)}{1-\left(1-G\left(s^{*}\right)\right)^{2}\left(1-p_{\emptyset}\right)^{2}} .
$$

Note next that by construction we have that

$$
\frac{\mathrm{d} A_{1}}{\mathrm{~d} s^{*}}-\frac{\mathrm{d} B_{1}}{\mathrm{~d} s^{*}}=0 \quad \text { at } s^{*}=s_{F B} .
$$

We show now that (A.7) implies at $s^{*}=s_{F B}$ that $\frac{\mathrm{d} A_{2}}{\mathrm{~d} s^{*}}-\frac{\mathrm{d} B_{2}}{\mathrm{~d} s^{*}}>0$ such that the firm must raise more debt than $2 D^{*}$ so as to implement the efficient credit policy. To show this, we have from an immediate comparison of the respective terms that

$$
\frac{\mathrm{d} A_{2}}{\mathrm{~d} s^{*}}-\frac{\mathrm{d} B_{2}}{\mathrm{~d} s^{*}}=2\left[\frac{\mathrm{d} A_{1}}{\mathrm{~d} s^{*}}-z \frac{\mathrm{d} B_{1}}{\mathrm{~d} s^{*}}\right],
$$

where

$$
z=\frac{2\left(1-G\left(s^{*}\right)\left(1-p_{\emptyset}\right)\right.}{1+\left(1-G\left(s^{*}\right)\right)\left(1-p_{\emptyset}\right)} .
$$

It thus remains to show that $z<1$, which follows as $z$ is increasing in the expression $(1-$ $\left.G\left(s^{*}\right)\right)\left(1-p_{\emptyset}\right)$ and equal to one in case $\left(1-G\left(s^{*}\right)\right)\left(1-p_{\emptyset}\right)=1$.

\section{References}

Allen, F., Carletti, E., Marquez, R., 2008. Credit market competition and capital regulation. Unpublished manuscript, Arizona State University.

Berger, A., Herring, R., Szegoe, G., 1995. The role of capital in financial institutions. J. Banking Finance 19, $393-430$.

Besanko, D., Kanatas, G., 1996. The regulation of bank capital: Do capital standards promote bank safety? J. Finan. Intermediation 5, 160-183.

Bhattacharya, S., Boot, A., Thakor, A., 1998. The economics of bank regulation. J. Money, Credit, Banking 30, 745-770.

Boyd, J., Prescott, E., 1986. Financial intermediary-coalitions. J. Econ. Theory 38, 211-232.

Calomiris, C., Kahn, C., 1991. The role of demandable debt in structuring optimal banking arrangements. Amer. Econ. Rev. 81, 497-513.

Demsetz, R., Strahan, P., 1997. Diversification, size, and risk at bank holding companies. J. Money, Credit, Banking 29, 300-313.

Demsetz, R., Saidenberg, M., Strahan, P., 1996. Banks with something to lose: The disciplinary role of franchise value. Fed. Reserve Bank New York Econ. Rev. (October), 1-14.

Diamond, D., 1984. Financial intermediation and delegated monitoring. Rev. Econ. Stud. 51, 393-414.

Diamond, D., Rajan, R., 2000. A theory of bank capital. J. Finance 55, 2431-2465.

Dynan, K., Johnson, K., Slowinski, S., 2002. Survey of finance companies. Fed. Reserve Bull. (October), 1-14.

Flannery, M., 1989. Capital regulation and insured banks' choice of individual loan default risks. J. Monet. Econ. 24, 235-258.

Flannery, M., 1994. Debt maturity and the deadweight cost of leverage: Optimally financing banking firms. Amer. Econ. Rev. 84, 320-331. 
Flannery, M., Rangan, M., 2004. What caused the capital build-up of the 1990s? Working paper No. 2004-03, FDIC Center for Financial Research.

Gambacorta, L., Mistrulli, P., 2004. Does bank capital affect lending behavior? J. Finan. Intermediation 13, $436-457$.

Gennotte, G., Pyle, D., 1991. Capital controls and bank risk. J. Banking Finance 15, 805-824.

Gorton, G., Winton, A., 2003. Financial intermediation. In: Constantinides, G., Harris, M., Stulz, R. (Eds.), Handbook of the Economics of Finance, Chapter 8, vol. I. North-Holland, Amsterdam.

Gropp, M., Heider, F., 2006. Bank capital structure. Unpublished manuscript, European Central Bank.

Hellmann, T., Murdock, K., Stiglitz, J., 2000. Liberalization, moral hazard in banking, and prudential regulation: Are capital requirements enough? Amer. Econ. Rev. 90, 147-165.

Inderst, R., Mueller, H., 2006. Informed lending and security design. J. Finance 61, 2137-2162.

Inderst, R., Mueller, H., 2007. A lender-based theory of collateral. J. Finan. Econ. 84, 826-859.

Kahn, C., Winton, A., 2004. Moral hazard and optimal subsidiary structure for financial institutions. J. Finance 59, 2531-2576.

Kwan, S., Eisenbeis, R., 1997. Bank risk, capitalization, and operating efficiency. J. Finan. Services Res. 12, $117-131$.

Lewellen, W., 1971. A pure financial rationale for the conglomerate merger. J. Finance 26, 521-537.

Marcus, A., 1984. Deregulation of bank financial policy. J. Banking Finance 8, 557-565.

Manove, M., Padilla, A., Pagano, M., 2001. Collateral vs. project screening: A model of lazy banks. RAND J. Econ. 32 , 726-744.

Rajan, R., 1992. Insiders and outsiders: The choice between informed and arm's length debt. J. Finance 47, $1367-1399$.

Reid, G., 1991. Staying in business. Int. J. Ind. Organ. 9, 545-556.

Saunders, A., Allen, L., 2002. Credit Risk Measurement. Wiley, New York.

Saunders, A., Cornett, M., 2003. Financial Institutions Management. McGraw-Hill, New York.

Stein, J., 1998. An adverse-selection model of bank asset and liability management with implications for the transmission of monetary policy. RAND J. Econ. 29, 466-487.

Stein, J., 2002. Information production and capital allocation: Decentralized vs. hierarchical firms. J. Finance 57, 18911922.

von Thadden, E.-L., 1995. Long-term contracts, short-term investments and monitoring. Rev. Econ. Stud. 62, 557-575.

Williamson, S., 1986. Costly monitoring, financial intermediation, and equilibrium credit rationing. J. Monet. Econ. 18, 159-179. 


\section{WORKING PAPERS}

1 (2006) Helmut Siekmann

$2(2006)$

3 (2006)

$4(2006)$

5 (2006)

$6(2006)$

7 (2006)

8 (2007)

9 (2007)

$10(2007)$
Helmut Siekmann

Helmut Siekmann

Reinhard H. Schmidt Aneta Hryckiewicz

Roman Inderst Holger M. Mueller

Felix Münnich

Roman Inderst Holger M. Mueller

Joachim Wieland

Helmut Siekmann

Henry Ordower

Helmut Siekmann
The Burden of an Ageing Society as a Public Debt (veröffentlicht in: European Public Law 2007 (13/3))

Die Unabhängigkeit von EZB und Bundesbank nach geltendem Recht und dem Vertrag über eine Verfassung für Europa

Die Verwendung des Gewinns der Europäischen Zentralbank und der Bundesbank

Financial Systems - Importance, Differences and Convergence

Financing A Portfolio of Projects

A Lender-Based Theory of Collateral

Staatsverschuldung als Herausforderung für die Finanzverfassung (veröffentlicht in: JZ 2006, S. 751 ff.)

Der Anspruch auf Herstellung von Transparenz im Hinblick auf die Kosten und Folgekosten der Steinkohlesubventionierung und den Börsengang der RAG AG

Demystifying Hedge Funds: A Design Primer (veröffentlicht in: UC Davis Business Law Journal 2007 (7/2), S. 323-372)

Die Spielbankabgabe und die Beteiligung der Gemeinden an ihrem Aufkommen - zugleich ein Beitrag zu den finanzverfassungsrechtlichen Ansprüchen der Gemeinden (veröffentlicht in: Organisation und Verfahren im sozialen Rechtsstaat, Festschrift für Friedrich E. Schnapp zum 
$11(2007)$

12 (2007)

$13(2007)$

14 (2007)

15 (2008)

16 (2008)

17 (2008)

18 (2008)

19 (2009)

20 (2009)
Symposium am

26.11.2007 in

Frankfurt am Main

Stefan Gerlach

Peter Kugler

Katrin Assenmacher-

Wesche

Stefan Gerlach

Toshitaka Sekine

Guntram B. Wolff

Helmut Siekmann

Katrin Assenmacher-

Wesche

Stefan Gerlach

Helmut Siekmann

Hans Genberg

Cho-Hoi Hui

Helmut Siekmann

Chun-Yu Ho

Wai-Yip Alex Ho
70. Geburtstag, Herausgegeben von Hermann Butzer, Markus Kaltenborn, Wolfgang Meyer, 2008, S.319-345)

Neuordnung der föderalen Finanzbeziehungen

Deflation and Relative Prices: Evidence from Japan and Hong Kong

Monetary Factors and Inflation in Japan

Schuldenanstieg und Haftungsausschluss im deutschen Föderalstaat: Zur Rolle des Moral Hazard

Föderalismuskommission II für eine zukunftsfähige Gestaltung der Finanzsystem nutzen

Ensuring Financial Stability: Financial Structure and the Impact of Monetary Policy on Asset Prices

Stellungnahme für die öffentliche Anhörung des Haushaltsausschusses zu dem Gesetzentwurf der Fraktion der SPD und Bündnis 90/Die Grünen für ein Gesetz zur Änderung der Hessischen Landeshaushaltsordnung

The credibility of The Link from the perspective of modern financial theory

Stellungnahme für die öffentliche Anhörung des Ausschusses für Wirtschaft, Mittelstand und Energie und des Haushalts- und Finanzausschusses des Landtags Nordrhein-Westfalen

Keine Hilfe für Banken ohne einen neuen

Ordnungsrahmen für die Finanzmärkte

On the Sustainability of Currency Boards:

Evidence from Argentina and Hong Kong 
21 (2009)

22 (2009)

23 (2009)

24 (2009)

25 (2009)

26 (2009)

27 (2009)

28 (2009)

29 (2009)

30 (2009)

31 (2009)
Stefan Gerlach

Tim Oliver Berg

Melanie Döge

Stefan Jobst

Helmut Siekmann

Helmut Siekmann

Helmut Siekmann

Roman Inderst

Hasan Doluca

Roman Inderst

Ufuk Otag

Roman Inderst

Holger Müller

Roman Inderst

Holger Müller

Roman Inderst

Holger Müller
The Risk of Deflation

Cross-country evidence on the relation between equity prices and the current account

Aktienrecht zwischen börsen- und

kapitalmarktorientiertem Ansatz

Die Schaffung von Einrichtungen der Finanzaufsicht auf EU-Ebene

Stellungnahme zu dem Vorschlag der

Sachverständigengruppe unter dem Vorsitz von Jacques de Larosière

Die Neuordnung der Finanzmarktaufsicht

Stabilisierung der WestLB AG durch Garantien des Landes NRW

Stellungnahme für die öffentliche Anhörung des Haushalts- und Finanzausschusses des Landtags Nordrhein-Westfalen am 29. Oktober 2009

Loan Origination under Soft- and Hard-Information Lending

Bank Competition and Risk-Taking When Borrowers Care about Financial Prudence

CEO Replacement under Private Information

Early-Stage Financing and Firm Growth in New Industries

Bank capital structure and credit decisions 